\title{
Ecological patterns of lichen species abundance in mixed forests of Eastern Romania
}

\section{Vicol}

Vicol, I. 2016. Ecological patterns of lichen species abundance in mixed forests of Eastern Romania. Ann. For. Res. 59(2): 237-248.

Abstract. The importance of this study consists in the knowledge of the ecological attributes characteristic to mixed forestry habitats and how they affect the structure of the lichen species abundances. The field activities were performed within five forest habitat types from Moldavia Province, characterised mainly by oak mixed forests, riparian mixed forests and mixed beech forests. The habitat variables, tree variables and the lichen species abundances were analysed to get informations on the structural disimilarities, on the one hand, and relationships on the other hand. Within this study no significant disimilarities were found out from abundance lichen species point of view. The lichen species abundances are a result of interactions between components of their microhabitat and macrohabitat. The correlation analysis pointed out the preferences of lichen species to their host trees, especially Quercus and Fraxinus, altitude and tree level variables as are aspect and mosses coverage. The regression analysis has highlighted that the changes in lichen species abundances are caused by macrohabitat level predictors such as host trees represented by Fraxinus. This study demonstrates that, structure of lichen species is influenced by attributes of mixed forest habitats; therefore maintaining the diversity of tree species and ensuring the continuous occurrence of forestry land is necessary for lichen and their habitat conservation.

Keywords Fraxinus, macrohabitat drivers, microhabitat particularities, Quercus, forest conservation

Authors. Ioana Vicol (ioana_vicol@yahoo.com) - Department of Ecology, Taxonomy and Nature Conservation, Institute of Biology Bucharest of Romanian Academy, 296 Splaiul Independentei, 060031 Bucharest, P.O. Box 56-53, Romania.

Manuscript received October 29, 2015; revised September 20, 2016; accepted September 27, 2016; online first November 3, 2016.

\section{Introduction}

The natural protected forest need to be main- tained due to their associated species, retain their features and aesthetic value (Hilbert \& Wiensczyk 2007). Furthermore, unlike to 
managed forests, the natural ones present a high quality of microhabitat and macrohabitat characteristics (Suija et al. 2007, Kubiak 2013, McMullin et al. 2014).

At the landscape level, epiphytic lichen communities are affected by climatical conditions, orographic variation and habitat fragmentation (Werth et al. 2005, Giordani 2006, Giordani \& Incerti 2008, Scheidegger \& Werth 2009).

At the habitat level, forest structure, management intensity (Franklin et al. 2002, Aragón et al. 2010, Morley \& Gibson 2010), matrix areas (Lindenmayer et al. 2000, Lindenmayer \& Franklin 2002, Debinski 2006, Driscol et al. 2013) forest continuity (Fritz \& Brunet 2010, Nascimbene et al. 2012) and tree species diversity (Jüriado et al. 2003, Leppik \& Jüriado 2008) are important predictors which affect epiphytic lichen communities.

At the tree level, the bark morphology, diameter, competition with other epiphytes (Leppik et al. 2011), bark pH (Mistry \& Berardi 2005, Thor et al. 2010) and aspect (Morley \& Gibson 2010) are attributes which influence epiphytic lichen species.

Background known studies from Romania, reveal important aspects about lichen species which are related to environmental factors and forest management. Thus, it was found that, within unmanaged forest habitats, lichen species are significantly affected by forest structure drivers (Ardelean et al. 2013, Vicol 2015a, Vicol 2015b) while in managed forest habitats the improper management have a negatively impact on lichen species (Ardelean et al. 2015).

Due to the influence of the biogeographical regions, on Romania territory there are different types of the habitats represented by a great divesity of the deciduous mixed forests and coniferous ones (Doniță et al. 2005). In the Moldavia Province, some protected areas are important genetic centers, especially to oak species and one of them (Medeleni Forest Reserve) represents "locus classicus" for Fraxino angustifoliae - Quercetum pedunculiflorae as- sociation. In the southern part of investigated area, the majority of forests were replaced with Robinia pseudacacia L. which have a negative impact of biodiversity (Sârbu et al. 2007).

The aim of this study consists in the finding out representative models based on the macrohabitat and microhabitat of the forestry drivers and how these affect the abundance of the lichen species. The main objectives of this study are: (i) point out differences regarding the lichen species abundances among the investigated forest habitat types; (ii) identify the main macrohabitat and microhabitat factors which influence the lichen species abundances and (iii) highlight the main predictors which affect lichen species abundances.

\section{Materials and methods}

\section{Studied area}

The Moldavian Plateau lies on $23085 \mathrm{~km}^{2}$, being situated in the eastern-northern part of Romania, between the Prut River, Obcinele Bucovinei, the Moldavian Subcarpathians, and in the northern-eastern part of the Romanian Plain. The basement of Moldavian Plateau is represented by the following structural entities: Moldavian Platform in north, Bârlad Platform as the western segment of the Scythian Platform and the Covurlui Platform in the southern extremity (Ielenicz \& Pătru 2005, Bălteanu et al. 2006). The Sarmatian deposits are represented by clays and sands with intercalations of limestone and sandstone that are seen on large plateau areas and Pliocene deposits, mainly marls and sands (Doniță et al. 1992, Bălteanu et al. 2006). Altitude is higher (400-500 m) in the north and lower (200-300 m) in the south (Doniță et al. 1992, Bălteanu et al. 2006). The climate suffers the effect of semi-arid continental influences. The annual mean temperatures range between $6.5^{\circ} \mathrm{C}$ and $10^{\circ} \mathrm{C}$ and precipitations are higher $(700 \mathrm{~mm})$ in the northern part and lower $(450 \mathrm{~mm})$ in the 


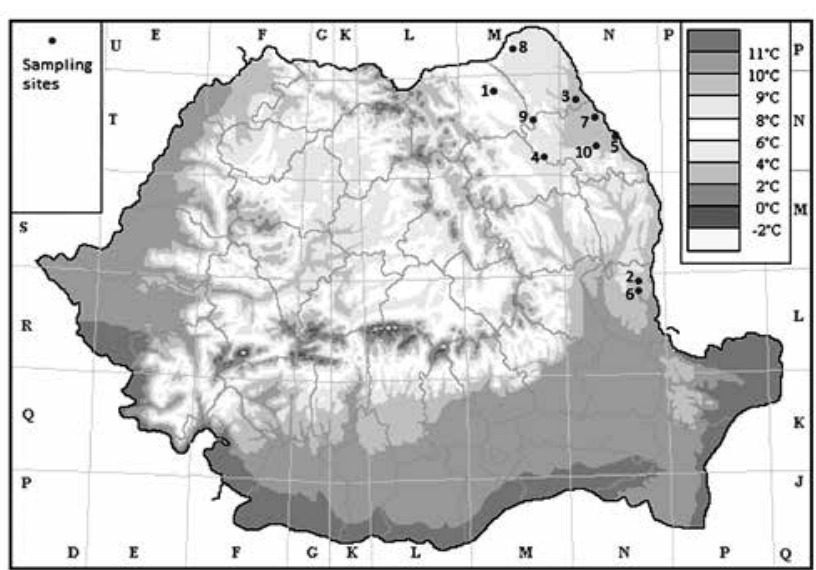

Figure 1 The location of the natural forest reserves subject to field works: (1) Crujana (Suceava county), (2) Breana-Roșcani (Galați), (3) Ciornohal-Călărași (Botoșani), (4) Ciritei-Mircești (Iași), (5) Medeleni (Iași), (6) Pogănești-Suceveni (Galați), (7) Roșcani-Trifești (Iași), (8) Stuhoasa-Suhărău (Botoșani), (9) Tudora Natural Reserve (Botoșani) and (10) Uricani (Iași).

southern part of the studied area (Doniță et al. 1992, Sârbu et al. 2007). In the northern part, luvic brown soils, frequently pseudogleyzated, are predominant. At altitudes above $200 \mathrm{~m}$, grey soils, chernozems, cambic chernozems, argillic chernozems and pelisols are spread. In the river floodplains there are halomorphic soils, alluvial soils and psamosols (Doniță et al. 1992).

The research were conducted in forest reserves covering five forest habitat types (Table 1).

\section{Sampling design}

At forest level. Within each FR, up to 16 sampling units of $10 \times 10 \mathrm{~m}$ were randomly selected. In the investigated area, a total of 160 sampling units of $100 \mathrm{~m}^{2}$ were recorded. The size of sampling unit is according to Prigodina-Lukošienè \& Naujalis (2006). In each sampling unit, a single tree found in the centre of the sampling units was selected. In total, up to 160 trees were tested. If there were more trees close to the centre of the sampling units, straight trunks without knobs and deep holes, trunks without splits under $1 \mathrm{~m}$ height into two branches, trees no less than $80 \mathrm{~cm}$ in diameter and trunks without removed bark were selected. In the studied area, 97 oaks, 5 maples, 3 cherries, 26 beeches, 19 ash-trees, 1 hornbeam, 4 poplars, and 5 lindens were sampled in total. The total number of each host tree species within each investigated reserve is given in Table 1 (Supporting Information).

At tree level. A frame of $20 \times 20 \mathrm{~cm}$ at a heigh of 1 $\mathrm{m}$ above the ground was set on each of the selected tree (Prigodina-Lukošienè \& Naujalis 2006). This sampling method was standardized by Estrabou et al. (2011), Estrabou et al. (2014). The tree species were selected according to their diameters. Thus, tree species with diameters higher than $80 \mathrm{~cm}$ were tested so that the frame of $20 \times 20 \mathrm{~cm}$ could be entirely included on the tested trunks. The tree diameters were measured at a height of $1 \mathrm{~m}$ above the ground. Within the investigated FR, 160 sampling units of $20 \times 20 \mathrm{~cm}$ were executed. Within each sampling unit, all specimens of each recorded lichen species were counted and then the depth of the rhytidome crevices was measured $(\mathrm{cm})$. The frame was split up in four quadrats of $10 \times 10 \mathrm{~cm}$, and within each quadrat, two measures of crevice depths were recorded (the one to the upper limit of $10 \times 10$ $\mathrm{cm}$, and the other to the lower limit of $10 \times 10$ $\mathrm{cm})$. In total, eight measures of crevice depth were recorded.

A part of macrovariables (the degree of the canopy openness, the covering with subarbuscle and arbuscle within each sampling unit of $10 \times 10 \mathrm{~m}$ and the cover with mosses and algae within each sampling unit of $20 \times 20 \mathrm{~cm}$ ) was recorded using a scale presented by Mistry \& 
Table 1 Information on the geographical, floristical composition and legislative framework of the studied forest habitat types

\begin{tabular}{|c|c|c|c|c|c|c|c|}
\hline $\begin{array}{l}\text { Name of } \\
\text { forest reserve }\end{array}$ & $\begin{array}{l}\text { Lat. } \\
(\mathrm{N})\end{array}$ & $\begin{array}{l}\text { Long. } \\
\text { (E) }\end{array}$ & $\begin{array}{l}\text { Forest } \\
\text { habitat }^{\text {type }}\end{array}$ & $\begin{array}{l}\text { Altitude } \\
(\mathrm{m})^{2}\end{array}$ & $\begin{array}{l}\text { Area } \\
(\text { ha })^{2}\end{array}$ & $\begin{array}{l}\text { Main } \\
\text { species }^{2}\end{array}$ & $\begin{array}{l}\text { Protected since } \\
\text { (documents) }\end{array}$ \\
\hline $\begin{array}{l}\text { Crujana } \\
\text { (Suceava) }\end{array}$ & 47.66 & 26.23 & R4125 & 330 & 39.4 & $\begin{array}{l}\text { Quercus robur L., } \\
\text { Carpinus betulus } \\
\text { L. }\end{array}$ & $\begin{array}{l}\text { 1973, Suceava County } \\
\text { Decision no. } 492 / 1973^{4} \text {; } \\
\text { Low no. } 5 / 2000^{5}\end{array}$ \\
\hline $\begin{array}{l}\text { Breana- } \\
\text { Roșcani } \\
\text { (Galati) }\end{array}$ & 45.91 & 27.98 & $\mathrm{R} 4157$ & $150-190$ & 400.0 & $\begin{array}{l}\text { Quercus } \\
\text { pubescens Willd. }\end{array}$ & Law no. $5 / 2000^{5}$ \\
\hline $\begin{array}{l}\text { Ciornohal- } \\
\text { Călăraşi } \\
\text { (Botoșani) }\end{array}$ & 47.61 & 27.23 & R4126 & $198-248$ & 200.0 & $\begin{array}{l}\text { Quercus } \\
\text { dalechampii Ten., } \\
\text { Tilia tomentosa } \\
\text { Moench., Cotinus } \\
\text { coggygria Scop., } \\
\text { C. betulus, } \\
\text { Acer tataricum L. }\end{array}$ & $\begin{array}{l}\text { 1975, Decree no. } \\
688 / 1975^{3} \text {; Botoșani } \\
\text { County Decision no. } \\
\text { 5/19956; Law no. } 5 / 2000^{5}\end{array}$ \\
\hline $\begin{array}{l}\text { Ciritei- } \\
\text { Mirceşti } \\
\text { (Iaşi) }\end{array}$ & 47.08 & 26.86 & $\mathrm{R} 4404$ & 188 & 26.3 & $\begin{array}{l}\text { Q. robur, Quercus } \\
\text { pedunculiflora K. } \\
\text { Koch., Fraxinus } \\
\text { angustifolia } \\
\text { Vahl., Fraxinus } \\
\text { excelsior L. }\end{array}$ & $\begin{array}{l}\text { 1994, Iaşi County } \\
\text { Decision no. } 8 / 1994^{6} \text {; } \\
\text { Law no. } 5 / 2000^{5}\end{array}$ \\
\hline $\begin{array}{l}\text { Medeleni } \\
\text { (Iaşi) }\end{array}$ & 47.28 & 27.65 & R4404 & $40-42$ & 105.0 & $\begin{array}{l}\text { Q. robur, } Q . \\
\text { pedunculiflora, } \\
\text { F. angustifolia, } F . \\
\text { excelsior }\end{array}$ & $\begin{array}{l}\text { 1994, Iaşi County } \\
\text { Decision no. 8/19946 }\end{array}$ \\
\hline $\begin{array}{l}\text { Pogănești- } \\
\text { Suceveni } \\
\text { (Galați) }\end{array}$ & 45.96 & 28.02 & $\mathrm{R} 4157$ & $150-200$ & 33.5 & $\begin{array}{l}\text { Q. dalechampii, } \\
\text { Q. pedunculiflora, } \\
\text { C. coggygria, } A . \\
\text { tataricum, Pyrus } \\
\text { elaeagrifolia } \\
\text { Pall., } Q . \\
\text { pubescens, } T . \\
\text { tomentosa }\end{array}$ & 2000 , Law no. $5 / 2000^{5}$ \\
\hline $\begin{array}{l}\text { Roșcani- } \\
\text { Trifești (Iaşi) }\end{array}$ & 47.43 & 27.38 & $\mathrm{R} 4126$ & $150-302$ & 150.0 & $\begin{array}{l}\text { Carpinus } \\
\text { orientalis Mill., } \\
\text { Q. dalechampii, } \\
\text { C. coggygria, C. } \\
\text { orientalis }\end{array}$ & $\begin{array}{l}\text { 1994, Iași County } \\
\text { Decision no. } 8 / 1994^{6} \text {; } \\
\text { Law no. } 5 / 2000^{5}\end{array}$ \\
\hline $\begin{array}{l}\text { Stuhoasa } \\
\text { Suharău } \\
\text { (Botoșani) }\end{array}$ & 48.15 & 26.35 & $\mathrm{R} 4120$ & $163-302$ & 100.0 & Fagus sylvatica $\mathrm{L}$. & $\begin{array}{l}\text { 1995, Botoșani County } \\
\text { Decision no. } 5 / 1995^{6} ; \\
\text { Law no. } 5 / 2000^{5}\end{array}$ \\
\hline $\begin{array}{l}\text { Tudora } \\
\text { (Botoșani) }\end{array}$ & 47.48 & 26.68 & $\mathrm{R} 4120$ & $300-350$ & 117.6 & $\begin{array}{l}\text { Taxus baccata L., } \\
\text { Fagus orietalis } \\
\text { Lipsky., F. } \\
\text { sylvatica }\end{array}$ & $\begin{array}{l}\text { 1975, Decree no. } \\
688 / 1975^{3} ; \text { Botoşani } \\
\text { County Decision no. } \\
5 / 1995^{6} ; \text { Law no } 5 / 2000^{5}\end{array}$ \\
\hline $\begin{array}{l}\text { Uricani } \\
\text { (Iași) }\end{array}$ & 47.13 & 27.48 & R4126 & $76-163$ & 68.0 & $\begin{array}{l}\text { Q. dalechampii, } \\
\text { Q. pedunculiflora }\end{array}$ & $\begin{array}{l}\text { 1973, Decree no. } 557^{3} ; \\
\text { Iași County Decision no. } \\
8 / 1994^{6} \text {; Law no. } 5 / 2000^{5}\end{array}$ \\
\hline
\end{tabular}


Table 1 (continuation)

Note. Abbreviations: R4125 (Moldavian mixed forests with sessile oak (Quercus petraea), beech (Fagus sylvatica), small-leaved linden (Tilia cordata) and Carex pilosa), R4126 (Moldavian mixed forests with sessile oak (Quercus petraea), beech (Fagus sylvatica), silver linden (Tilia tomentosa) and Carex brevicollis), R4157 (Danubian-west-pontic steppe forests of pedunculate oak (Quercus pedunculiflora) and Acer tataricum), R4404 (Mixed danubian-panonic forests with common oak (Quercus robur), ash (Fraxinus sp.), elm (Ulmus sp.) and Festuca gigantea), R4120 (Moldavian mixed forests with beech (Fagus sylvatica), silver linden (Tilia tomentosa) and Carex brevicollis); ${ }^{1}$ Doniță et al. 2005; ${ }^{2}$ Sârbu \& al. 2007; ${ }^{3}$ Mohan \& Ardelean 2006; ${ }^{4} \mathrm{http} / /$ www.anpm.ro/web/ apm-suceava/rapoarte-anuale; ${ }^{5}$ http://www.anpm.ro/legislatie; ${ }^{\circ} \mathrm{http} / / /$ biodiversitatecbc-apmis.ro/new/down/Buletin_informativ_2.pdf.

Berardi (2005): 1 - weak degree of the canopy openness, low coverage with subarbuscle and arbuscle, low coverage with mosses and algae; 2 - moderate degree of the canopy openness, moderate coverage with subarbuscle and arbuscle, moderate coverage with mosses and algae; 3 - strong degree of the canopy overlapping, high coverage with subarbuscle and arbuscle and high coverage with mosses and algae. The scale corresponds to a coverage range that was chosen arbitrarily as follow: $1-0-33 \%, 2$ - 33$66 \%, 3-66-99 \%$. The field activities were performed during June-Octomber 2013.

Host trees including measurements on diameters and the rhytidome crevice depth within each investigated FR are presented in Table 2 (Supporting Information). Within the investigated forest habitats, the floristic composition of the host tree species is presented in Table 3 (Supporting Information).

Sample analysis. The lichen species which were not identified in the field were transported to laboratory for further identification. The lichen species identification used lichen keys (Moruzi \& Toma 1971, Purvis et al. 1994, Ciurchea 2004), stereomicroscope (Zeizz Stereo CL 1500 ECO), and optical microscope (Zeizz Scope A1). Lichen species were identified based on the microscope slides and chemical reagents as: iodine-potassium iodide (IIK), chlorine $\left(\mathrm{Cl}_{2}\right)$, potassium hydroxide $(\mathrm{KOH})$, calcium chloride $\left(\mathrm{CaCl}_{2}\right)$ and paraphenylenediamine $(\mathrm{Pd})$. The identification of the tree species followed Ciocârlan (2009).

The nomenclature used in lichens was MycoBank (www.mycobank.org), while in cormophytes was The International Plant Name Index (www.uk.ipni.org).

\section{Statistical analysis}

The statistical analysis was performed at the habitat type level. Within the studied area were identified five habitat types (see table 1); thus for each habitat type there are three subset variables such as macrovariables (habitat level variables), microvariables (tree level variables) and lichen species abundance (response variables).

Macrovariables (altitude, the degree of the canopy openness, the cover with subarbuscles and arbuscles with sampling units of $10 \times 10$ $\mathrm{m}$ and host trees) microvariables (aspect, coverage with mosses and algae within sampling units of $20 \times 20 \mathrm{~cm}$, diameter of the host trees, bark crevice depth) and lichen species abundances were analysed using univariate, bivariate and multivariate methods.

The lichen species abundances were analysed using relative abundance that was calculated according to the following formula (Wallace 1878 cited by Hurlbert 1971):

$$
\pi_{i}=N_{i} / N \times 100, \text { where }
$$

$\pi_{i}$ - relative abundance, $N_{i}$ - the total number of specimens of a particular species; $N$ - the total number of specimens of all species.

The lichen species, which was found in 1 or 2 sampling units, was not taken into account. Removal of the rare lichen species is a useful way of reducing the bulk and noise in the data set without losing much information (McCune 
et al. 2002).

The Shapiro-Wilk test (Ditham 2011) was first used to verify the data distribution and it has shown a non-normal distribution of the data $(P<0.05)$.

Log transformation is useful for diverse environmental, habitat and species response variables especially when there is a high degree of variation within variables or when there is a high degree of variation among attributes within a sample (McCune et al. 2002); therefore, macrovariables, microvariables and lichen species abundances were log transformed.

As dummy variables, the aspect and host trees have been coded for each different level of this factor. Thus, for a sample (habitat type) "a particular value of the factor corresponding to a dummy variables has the value 1.0 for this sample, and the other dummy variables have a value of 0.0 for the same sample (Lepš \& Šmilauer 2003).

Kendall rank order correlation was used to find out significat relationships between lichen species abundances (response variables) and variables at habitat and tree level (within the same habitat type), respectively. Thus, each abundance of the lichen species was analysed to each macrovariable and microvariable for each habitat type in part. Monte Carlo permutation test was based on 9999 random replicates (Hammer et al. 2001).

Polynomial regression analysis of the first order was used to find significant predictors which affect lichen species abundances (Legendre \& Legendre 2012). Each macro and micro variables versus each lichen species abundances were analysed for the same forest habitat type in part. The chi-squared and Akaike Information Criterion values must be as lower as possible to a significant fit of data set (Hammer et al. 2001).

To detect dissimilarities among investigated forest habitats on basis of the lichen species abundances, cluster analysis was used (Jongman et al. 1995). As a measure of dissimilarity among investigated habitats, Chord Distance
Coefficient was selected (Ludwig \& Reynolds 1988). To find out significant differences as regard lichen species abundances among investigated forest habitats the Mann-Whitney U test was used. Thus, the five forest habitats were compared 2 by 2 based on their lichen species abundances (Ditham 2011).

To evaluate which are the lichen species primarily responsible for the dissimilarities between the investigated forest habitat types, the SIMPER method was used (Hammer et al. 2001). The Chord Distance Coefficient was selected to calculate the similarity percentage between samples (Ludwig \& Reynolds 1988). Lichen species with a percentage value lower than $0.50 \%$ were not taken into account. All statistical analyses (normal distribution, data transformation, cluster analysis, SIMPER, Mann-Whitney U test, non-parametric correlation and regression analysis) were performed using PAST software (Hammer et al. 2001).

\section{Results}

In the studied forest habitats, 43 lichen species were found (Table 4 in Supporting Information). The statistical analysis was performed by eliminating 23 lichen species from their total number, because they were in one or two sampling units accordingly, only 20 lichen species were statistically analysed. As was expected, nitrophilous lichen species such as Phaeophyscia nigricans (Flk.) Moberg., Physcia aipolia (Ehrh. ex Humb.) Fürnr., Phaeophyscia orbicularis (Nëck.) Moberg., Physconia distorta (With.) J. R. Laudon, Physconia enteroxantha (Nyl.) Poelt, recorded higher values of their relative abundance in the forest habitats mainly represented by oak. In other regards, Graphis scripta (L.) Ach. and Pyrenula nitida (Weig.) Ach. were more abundant in forest habitats consisting mainly in beech (Table 1 and Table 4 in Supporting Information). An important conservation aspect of this research consists in the identification of the red-listed 
lichen species Hypotrachyna sinuosa (Sm.) Hale (1975) on $Q$. robur in a mixed oak forestry habitat.

Cluster analysis indicated that groups represented by R4126, R4157 and R4404 forest habitat types were slightly distinct as regards the recorded relative abundance of the lichen species as against forest habitat group such as R4120 and R 4125 due to the lower value (0.58) of the Cophenetic Correlation Coefficient (Fig. 2). The first group of forest habitat types consisted of oak, ash and linden in a great deal unlike, the second group of the tested trees, which was predominantly represented by beech (Table 1 Supporting Information). Based on Mann-Whitney U test, no significant differences were pointed out among forest habitat types in terms of lichen species abundances (Table 5 in Supporting Information). Also, SIMPER analysis did not show a considerable contribution concerning lichen species abundances among the studied forest habitats (Table 6 in Supporting Information).

Based on the non-parametric correlation, significant relationships were found between lichen species abundances and habitat level variables in the following studied forest habitats: R4125 among G. scripta and Quercus $(-0.54, \mathrm{p}<0.05)$, R4126 among $P$. orbicularis and Fraxinus $(0.75, \mathrm{p}<0.05), \mathrm{R} 4157$ among $P$. enteroxantha and altitude $(-0.35, \mathrm{p}$ $<0.05$ ), among Lecidella elaeochroma (Ach.) M. Choisy and Fraxinus $(0.73, \mathrm{p}<0.05)$ and tree level variables in the forest habitat, as are R4126, among Xanthoria fallax (Hepp.) Arn. and trunk orientation towards the east $(0.81, \mathrm{p}$ $<0.05)$, R4157 among $P$. distorta, and the covering in mosses $(0.45, \mathrm{p}<0.05)$, and R4120 among $P$. nitida and trunk orientation towards the west $(-0.52, \mathrm{p}<0.05)$.

The descriptive modelling indicated host trees as significant predictors. Thus, the abundances of lichen species are affected especially by habitat level predictors such as ash species (Table 2).

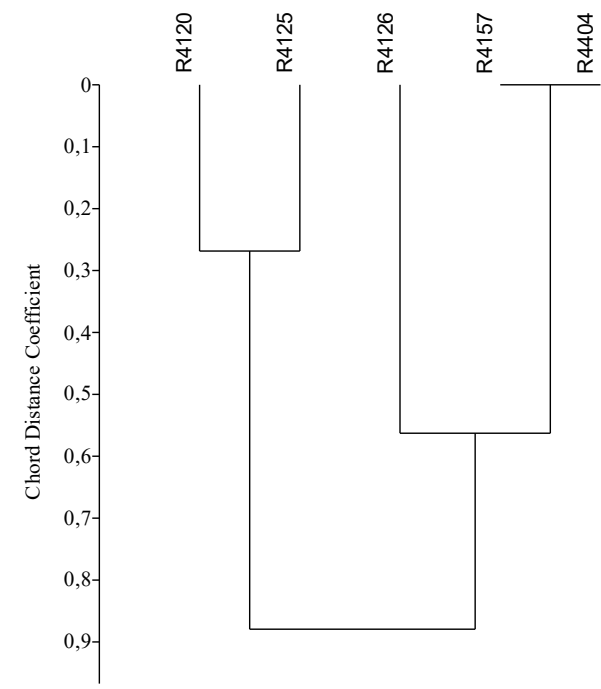

Figure 2 Dendrogram of the investigated forest habitats carried out based on lichen species abundances. Abbreviations follow the Table 1.

\section{Discussion}

According to the obtained results, nitrophilous lichen species are more abundant in the studied area. The studied forest habitats are integrated within an agricultural landscape; therefore lichen species with preferences to organic enrichment substrata are dominant. In a similar study performed in the northern part of Thailand, the predominance of the nitrophilous lichen species, especially from Physciaceae Family, is caused by agricultural intensive practices at lowland level with lower atmospheric humidity and higher temperature (Saipunkaew et al. 2005). Generally, the Physciaceae Family is represented by xerophilous, termophilous and preferences for high values of the substrata eutrophication (Wirth 2010). The higher bark pH of the ash tree (Laundon 1963) may be an explanation of the higher abundance of some nitrophilous lichen species such as: $P$ orbicularis and L. elaeochro$m a$ on its trunks. The higher abundance of nitrophilous lichen species in agricultural and livestock stands is influenced by well-lighted 
Table 2 Results of the regression analysis on habitat and tree level predictors

\begin{tabular}{|c|c|c|c|c|c|c|c|c|}
\hline \multirow[b]{2}{*}{$\begin{array}{l}\text { Type of } \\
\text { habitat }\end{array}$} & \multirow[b]{2}{*}{$\begin{array}{l}\text { Sample } \\
\text { size }(n)\end{array}$} & \multirow[b]{2}{*}{$\begin{array}{l}\text { Response } \\
\text { variables }\end{array}$} & \multirow[b]{2}{*}{$\begin{array}{l}\text { Habitat level } \\
\text { predictors }\end{array}$} & \multicolumn{5}{|c|}{ Significance statistics } \\
\hline & & & & $\begin{array}{l}\text { Chi- } \\
\text { square }\end{array}$ & $\begin{array}{l}\text { Akaike } \\
\text { Information } \\
\text { Criterion }\end{array}$ & $r^{2}$ & $F$ & $p$ \\
\hline R4126 & 34 & P. orbicularis & Fraxinus & 0.04 & 8.04 & 0.66 & 7.89 & 0.04 \\
\hline R4157 & 31 & $\begin{array}{l}\text { Lecidella } \\
\text { elaeochroma }\end{array}$ & Fraxinus & 0.04 & 8.04 & 0.66 & 8.06 & 0.04 \\
\hline
\end{tabular}

Note. The abbreviations are common to Table 1 .

microhabitats and high enrichment in nutrients of substrata (Giordani \& Incerti 2008, Aragón et al. 2010).

In the forest habitats represented mainly by beech, crustose lichen species are more abundant on their trunks due to smooth bark. Similar results have been obtained by Bollinger et al. (2007) in Switzerland, Leppik et al. (2011) in Estonia and Ekman et al. (2013) in Sweden, who found that crustose lichen species are related to trees with smooth bark, among which Fagus sylvatica is one of the host trees.

As an important attribute of mixed forests, the diversity of tree species, especially Quercus and Fraxinus, is associated to an increase of the abundance lichen species. Other studies pointed out that the higher of the abundance lichen species on ash tree is due to their rough bark and capacity to store a large amount of water (Moe \& Botnen 1997). Due to the variability of the bark texture, the lichen propagules can became trapped and develop on rough surfaces more easly than on smooth surfaces (Mistry \& Berardi 2005, Mežaka et al. 2008). Another influence of bark texture on lichen species abundance is based on the higher water holding capacity and the porosity of the softbarked trees such as Ulmus ssp. and Fraxinus ssp. which give up water more slowly than hard-barked trees, such as Quercus ssp. (Mistry \& Berardi 2005).

The aspect (especially the eastern part of trunks), is more or less correlated to sunlight conditions. The well-lit trunks are adequate substrata to foliose thalli. Generally, foliose thalli prefer better illuminated substrata (Wirth 2010) therefore their abundances increasing with solar light (Moe \& Botnen 1997, Moe \& Botnen 2000, Franklin et al. 2002, Jüriado et al. 2009, Hauck 2011).

Generally, the changes in lichen species abundance are caused by host tree (ash species) as significant predictors identified within the studied forestry habitats.

The protected forest habitats are widely considered a refuge for many species, but they are also connected to managed stands; therefore, an important management tool would be that, in the managed stands, the cutting of trees should be selective in order to create a matrix which consists in an uniform patch, including trees of different ages, with diverse microhabitat and macrohabitat features.

\section{Conclusions}

In forest habitats where oak dominates, the nitrophilous lichen species are more abundant, most likely due to agricultural influences. Otherwise, in the forest habitats well represented by beech, there are two lichen species that are common, namely $P$. nitida and G. scrip$t a$, which are rather abundant. Lichen species abundances are significantly related to macrohabitat drivers such as host trees and altitude, and also to microhabitat drivers such as aspect and mosses covering. Significant predictors which affect lichen species abundances are mainly host trees consisting in Fraxinus. It 
has been found that there are no dissimilarities among forest habitat types in terms of lichen species abundance. The oak and ash as mainly constituent element of the studied forestry habitats have indeed a determinant role in lichen species abundance.

\section{Acknowledgements}

The author would like to thank to Ioan Vicol, Constanța Vicol, George-Mihai Costache, Gabriel Rizea and Ion Caragea for assistance in field activities. I am deeply grateful to an anonimous reviewer for valuable comments on the manuscript. I would also like to thank to the staff of the National Forest Administration - ROMSILVA Branches: Corneliu Parascan (Iași), Sorin Corduneanu (Botoșani), Sorin Ciobanu (Suceava), Valentin Hahuie and Dorel Folea (Galați) for allowing me to carry out activities in the field. Moreover, I would like to thank Acad. Dan Munteanu and Simona Mihăilescu (Commission for the Nature Monuments Protection of Romanian Academy) for the permission to work in nature reserves. Many thanks to Sorin Ștefănuț for map providing and technical assistance. The study was funded by project no. RO1567-IBB03/2014 of the Institute of Biology - Romanian Academy.

\section{References}

Agency of Environment Protection Iași, 2008. Ariile naturale protejate din județele Botoșani, Iași, Vaslui, Galați, Management bilateral România - Republica Moldova pentru conservarea biodiversităţii în zona de graniţă dintre cele 2 țări. [Natural protected areas from Botoșani, Iași, Vaslui, Galați counties, Mutual management Romania-Republic Moldova for biodiversity conservation on the border between the two countries]. Web: http://biodiversitatecbc-apmis.ro/new/down/Buletin informativ_2.pdf. Accessed: 09.06.2016.

Aragón G., Martínez I., Izquierdo P., Belinchón R., Escudero A., 2010. Effects of forest management on epiphytic lichen diversity in Mediterranean forests. Applied Vegetation Science 13: 183-194. DOI: 10.1111/j.1654109X.2009.01060.x.

Ardelean I.V., Keller C., Cristea V., Scheidegger C., 2013.
Lichen species diversity of Pinus mugo scrubs compared to adjacent habitat types in the Rodnei Mts. National Park (Romania). Contribuții Botanice 48: 59-68.

Ardelean I.V., Keller C., Scheidegger C., 2015. Effect on management on lichen species richness, ecological traits and community structure in the Rodnei Mountains Natinal Park (Romania). PloS ONE 10(12): e0145808. DOI: 10.1371/journal.pone.0145808.

Bălteanu D., Badea L., Buza M., Niculescu G., Popescu C., Dumitrașcu M., 2006. Romania space, society, environment. The Publishing House of the Romanian Academy, Bucharest, 384 p.

Bollinger, J., Bergamini A., Stofer S., Kienast F., Scheidegger C., 2007. Predicting the potential spatial distributions of epiphytic lichen species at the landscape scale. Lichenologist 39(3): 279-291. DOI:10.1017/ S0024282907006652.

Ciurchea M., 2004. Determinatorul lichenilor din România [The lichen flora of Romania]. Editura Bit, Iași, 488 p.

Ciocârlan V., 2009. Flora ilustrată a României [Illustrated flora of Romania]. Pteridophyta et Spermatophyta. Editura Ceres, Bucharest, $1141 \mathrm{p}$.

Debinski D.M., 2006. Forest fragmentation and matrix effects: the matrix does matter. Journal of Biogeography 33: 1791-1792.

Doniță N., Ivan D., Coldea G., Sanda V., Popescu A., Chifu T., Paucă-Comănescu M., Mititelu D., Boșcaiu N., 1992. Vegetația României [Vegetation of Romania]. Editura Tehnică Agri $\neg$ colă, Bucharest, 407 p.

Doniță N., Popescu A., Paucă-Comănescu M., Mihăilescu S., Biriş I.V., 2005. Habitatele din România [The Romania's habitats]. Editura Tehnică Silvică, Bucharest, $442 \mathrm{p}$.

Driscol D.A., Banks S.C., Barton S.P., Lindenmayer D.B., Smith A.L., 2013. Conceptual domain of the matrix in fragmented landscapes. Trends in Ecology \& Evolution 28(10): 605-613. DOI: 10.1016/j.tree.2013.06.010

Dytham C., 2011. Choosing and using statistics, A biologist's guide, 3th Edition, Wiley-Blackwell Publishing House, Oxford, 316 p.

Ekman S., Aquirre-Hudson B., Arup U., Fritz Ö., Svensson M., 2013. Rhaphidicyrtis trichosporella new to Sweden. Graphis scripta 25: 6-11.

Estrabou C., Filippini E., Soria J.P., Schelotto G., Rodríguez J. M., 2011. Air Quality monitoring system using lichens as bioindicators in Central Argentina. Environmental Monitoring and Assessment 182(1): 375-383.

Estrabou C., Quiroga C., Rodríguez J. M., 2014. Lichen community diversity on a remnant forest in south of Chaco region (Cordoba, Argentina). Bosque 35(1): 49-55. DOI: 10.1007/s10661-011-1882-4

Franklin J.F., Spies T.A., Van Pelt R., Carey A.B., Thornburgh D.A., Berg D.R., Lindenmayer D.B., Harmon M.E., Keeton W.S, Shaw D.C., Bible K., Chen J., 2002. Disturbances and structural development of natural forest ecosystems with silvicultural implications, using Douglas-fir forests as an example. Forest of Ecology and Management 155(1-3): 399-423. DOI:10.1016/ 
S0378-1127(01)00575-8.

Fritz O., Brunet J., 2010. Epiphytic bryophytes and lichens in Swedish beech forests-effects of forest history and habitat quality. Ecological Bulletins 153: 95-107.

Giordani P., 2006. Variables influencing the distribution of epiphytic lichens in heterogeneous areas: A case study for Liguria, NW Italy. Journal of Vegetation Science 17: 195-206.

Giordani P., Incerti G., 2008. The influence of climate on the distribution of lichens: a case study in a borderline area (Liguria, NW Italy). Plant Ecology 195: 257-272. DOI: $10.1007 / \mathrm{s} 11258-007-9324-7$.

Hammer Ø., Harper D.A.T., Ryan P.D., 2001. PAST: Paleontological Statistics Software Package for Education and Data Analysis. Version 2.13. Paleo Electronica 4: 1-9.

Hauck M., 2011. Site factor controlling epiphytic lichen abundance in northern coniferous forests. Flora 206: 81-90. DOI:10.1016/j.flora.2010.02.001.

Hilbert J., Wiensczyk A., 2007. Old-growth definitions and management: A literature review. BC Journal of Ecosystems and Management 8(1): 15-31.

Hurlbert S.H., 1971. The nonconcept of species diversity: a critique and alternative parameters. Ecology 52(4): 577-586. DOI: $10.2307 / 1934145$

Ielenicz M., Pătru I., 2005. Geografia fizică a României [Physical geography of Romania]. Vol 1. Editura Universitară, Bucharest, $255 \mathrm{p}$.

International Mycological Association, Mycobank Database 2004. Web: www.mycobank.org. Accessed: 09.2015 .

Jongman R.H.G., Ter Braak C.J.F., Van Tongeren O.F.R., 1995. Data analysis in community and landscape ecology. Cambridge University Press, Cambridge, 299 p. DOI: $10.1017 / \mathrm{CBO} 9780511525575$

Jüriado I., Paal J., Liira J., 2003. Epiphytic and epixylic lichen species diversity in Estonian natural forests. Biodiversity and Conservation 12: 1587-1607. DOI: 10.1023/A:1023645730446

Jüriado I., Liira J., Paal J., 2009. Diversity of epiphytic lichens in boreo-nemoral forests on the North-Estonian limestone escarpment: the effect of tree level factors and local environmental conditions. Lichenologist 41(1): 81-96. DOI: $10.1017 / \mathrm{S} 0024282909007889$

Kubiak D., 2013. The significance of old-growth forests in maintaining lichen diversity-an example from the remnants of the Mazovian Forest. Forest Research Papers 74(3): 245-255. DOI: 10.2478/frp-2013-0024.

Laundon J.R., 1963. The taxonomy of sterile crustaceous lichens in the British Isles. Lichenologist 2(1): 101-151. DOI: $10.1017 / \mathrm{S} 002428296300013 \mathrm{X}$

Legendre P., Legendre L., 2012. Numerical Ecology. Third Edition. Elsevier, 990 p.

Leppik E., Jüriado I., 2008. Factors important for epiphytic lichen communities in wooded meadows of Estonia. Folia Cryptogamica Estonica 44: 75-87. DOI: 10.1017/ S002428291100003X

Leppik E., Jüriado I., Liira J., 2011. Changes in stand structure due to the cessation of traditional land use in wooded meadows impoverish epiphytic lichen communities. Lichenologist 43(3): 257-274. DOI:10.1017/ S002428291100003X.

Lepš J., Šmilauer P., 2003. Multivariate analysis of ecological data using $\mathrm{CANOCO}^{\mathrm{TM}}$. Cambridge University Press, Cambridge, 269 p. DOI: 10.1017/ CBO9780511615146

Lindenmayer D.B., Margules C.R., Botkin D.B., 2000. Indicators of biodiversity for ecologically sustainable forest management. Conservation Biology 14(4): 941950. DOI: 10.1046/j.1523-1739.2000.98533.x.

Lindenmayer D.B., Franklin J.F., 2002. Conserving forest biodiversity: a comprehensive multiscaled approach. Island Press, Washington, 351 p. DOI: 10.1046/j.15231739.2000.98533.x

Ludwig A.I., Reynolds J.F., 1988. Statistical ecology. A primer on methods and computing. John Wiley \& Sons Publishing House, New York, 337 p.

Mežaka A., Brūmelis G., Piterāns A., 2008. The distribution of epiphytic bryophyte and lichen species in relation to phorophyte characters in Latvian natural old-growth broad leaved forests. Folia Cryptogamica Estonica 44: 89-99.

McCune B., Grace J.B., Urban D.L., 2002. Analysis of ecological communities. MjM Software Design, Oregon, $304 \mathrm{p}$.

McMullin R.T., Maloles J.R., Earley C., Newmaster S.G., 2014. The arboretum at the University of Guelph, Ontario: an urban refuge for lichen biodiversity. North American Fungi 9(5): 1-16. DOI: 10.2509/naf2014.009.005.

Ministry of Environment, Water and Forests, National Agency for Environmental Protection 2016. Legislație [Legislation]. Web: http://www.anpm.ro/legislatie. Accessed: 09.06.2016.

Ministry of Environment, Water and Forests, Agency of Environmental Protection Suceava 2016. Domenii. Sinteze și Rapoarte [Domains. Synthesis and Reports]. Web: http://www.anpm.ro/web/apm-suceava/rapoarte-an $\neg$ uale. Accessed: 09.06.2016.

Mistry J., Berardi A., 2005. Effects of phorophyte determinants on lichen abundance in the cerrado of central Brazil. Plant Ecology 178: 61-76. DOI 10.1007/s11258004-2493-8.

Moe B., Botnen A., 1997. A quantitative study of the epiphytic vegetation on pollarded trunks of Fraxinus excelsior at Havrå, Osterøy, western Norway. Plant Ecology 129: 157-177. DOI: 10.1023/A:1009720132726

Moe B., Botnen A., 2000. Epiphytic vegetation on pollarsded trunks of Fraxinus excelsior in four different habitats at Grinde, Leikanger, western Norway. Plant Ecology 151: 143-159. DOI: 10.1023/A:1026585911823

Mohan G., Ardelean A., 2006. Parcuri și rezervații naturale din România [Parks and nature reserves of Romania]. Editura Victor B Victor, București, $164 \mathrm{p}$.

Morley S.E., Gibson M., 2010. Successional changes in epiphytic rainforest lichens: implications for the management of rainforest communities. Lichenologist 
42(3): 311-321. DOI: 10.1017/S0024282909990570.

Moruzi C., Toma N., 1971. Lichenii. Determinator de plante inferioare [Lichens. Determinator of lower plants]. Editura Didactică și Pedagogică, București, 221 p.

Nascimbene J., Marini L., Ódor P., 2012. Drivers of lichen species richness at multiple spatial scales in temperate forests. Plant Ecology \& Diversity 5(3): 355-363. DOI: 10.1080/17550874.2012.735715.

Prigodina-Lukošienė I., Naujalis J.R., 2006. Principal relationship among epiphytic communities on common oak (Quercus robur L.) trunks in Lithuania. Ekologija 2: $21-25$.

Purvis O.W., Coppins B.J., Hacksworth D.L., James P.W., Moore D.M., 1994. The lichen flora of Great Britain and Ireland. Natural History Museum Publications in association with The British Lichen Society, London, $710 \mathrm{p}$.

Saipunkaew W., Wolseley P., Chimonides J., 2005. Epiphytic lichens indicators of environmental health in the vicinity of Chiang Mai city, Thailand. The Lichenologist 37(4): 345-356. DOI: 10.1017/S0024282905014994

Sârbu A., Sârbu I., Oprea A., Negrean G., Cristea V., Gheorghe C., Cristurean I., Popescu Ghe., Oroian S., Tănase C., Bartók K., Gafta D., Anastasiu P., Crișan F., Costache I., Goia I., Marușca T., Oțel V., Sămărghițan M., Hențea S., Pascale G., Răduțoiu D., Baz A., Boruz V., Pușcaș M., Hirițiu M., Stan I., Frink J., 2007. Arii speciale pentru protecția și conservarea plantelor în România [Special areas for protection and conservation of plants in Romania]. Victor B Victor, Bucharest, 396 p.

Scheidegger C., Werth S., 2009. Conservation strategies for lichens: insights from population biology. Fungal Biology Reviews 23(3): 55-66. DOI:10.1016/j. fbr.2009.10.003.

Suija A., Lõhmus P., Jüriado J., 2007. The lichen biota of the Agusalu and Puhatu reserves (Estonia): the first overview. Forestry Studies 47: 99-116.

The International Plant Names Index 2012. Web: http:// www.ipni.org. Accessed: 05.2016.

Thor G., Johansson P., Jönsson T., 2010. Lichen diversity and red-listed species relationships with tree species and diameter in wooded meadows. Biodiversity and Conservation 19: 2307-2328. DOI 10.1007/s10531010-9843-8.
Vicol I., 2015. Effect of the old-growth forest attributes on lichen species abundance: a study performed within Ceahlău Natinal Park (Romania). Cryptogamie, Mycologie 36(4): 399-407. DOI: $10.7872 /$ crym/v36. iss4.2015.399

Vicol I., 2015. Synecological structure of the lichen synusiae within forest natural reserves from Moldavian Plateau (Romania) Turkish Journal of Botany 39(1): 189-197. DOI: 10.3906/bot-1312-10.

Wallace A.R., 1878. Tropical nature and other essays. MacMillan and Co., London, 356 p. DOI: 10.5962/bhl. title. 1261

Werth S., Tømmervik H., Elvebakk A. 2005. Epiphytic macrolichen communities along regional gradients in northern Norway. Journal of Vegetation Science 16:199-208. DOI: 10.1111/j.1654-1103.2005.tb02356.x

Wirth V., 2010. Ökologische Zeigerwerte von Flecht $\neg$ en - erweiterte und aktualisierte Fassung [Ecological indicators values of lichens enlarged and updated species list]. Herzogia 23(2): 229-248. DOI: 10.13158/ heia.23.2.2010.229

\section{Supporting Information}

Table 1 The number of sampled trees in each investigated habitat type

Table 2 The host tree measurements on perimeters and the rhytidome crevice depth in each investigated habitat types

Table 3 The host trees identified in each habitat type

Table 4 List of the lichen species relative abundance (\%) and their distribution in the investigated forest habitat types

Table 5 Results of the Mann-Whitney U test in terms of differences between habitat types based on lichen species abundances

Table 6 SIMPER analysis performed on lichen species abundances in overall forest habitats 